\title{
Pembinaan penyusunan laporan keuangan dan pemberdayaan pemasaran berbasis e-commerce pada ukm bank sampah mandiri kota batam (a)
}

\author{
Dian Efriyenti ${ }^{1}$ Tukino $^{2}$
}

\begin{abstract}
This community service report presents details of activities carried out in the form of financial reports preparation and marketing empowerment based on e-commerce for small and medium-sized enterprises (SME) of Bank Sampah Mandiri in the city of Batam. Based on the results of interviews in the field, this Bank Sampah Mandiri's small and medium-sized enterprises has problems in marketing production and financial records. The methods used were the combinations of seminars, coachings and survers. The results of the program were threefold. Firstly, the participant feel there is still a need for adjustments to the preparation of financial statements with financial accounting standards for entities without public accountability. Secondly, there has been a separation of financial reports that have been commonly prepared by SMEs through business profits and personal cash. Finally, the SME social media pages are existing and the participant understand how to incorporate social media to maximize sales.
\end{abstract}

\section{Keywords}

Development of financial report preparation, empowerment of e-commerce based marketing, mandiri waste bank smes.

\section{Pendahuluan}

Kota Batam adalah kota di Kepulauan Riau dengan populasi terbesar ketiga di wilayah Sumatera, setelah Medan dan Palembang. Menurut Dinas Kependudukan dan Catatan Sipil Kota Batam (2015), populasi Kota Batam mencapai 1.153.860 orang. Kota Batam adalah kota industri terbesar di antara beberapa kota di Indonesia. Dalam bisnis, Kota Batam tidak tertinggal, baik industri maupun rumah tangga. Banyak usaha kecil dan menengah di Kota Batam yang terlibat dan menyerap banyak tenaga kerja (Kementrian Keuangan, 2016).

Berdasarkan hasil analisis pengabdian Afrida et al. (2018) permasalahan utama usaha atau bisnis yang sedang berkembang adalah pengetahuan terbatas mitra manajemen keuangan, minimnya penguasaan teknologi informasi, terutama teknologi pemasaran internet, dan juga kurangnya inovasi dalam manajemen bisnis dan pemahaman para pebisnis yang kurang memadai dalam penyusunan laporan keuangan.

Sejalan dengan itu, Harahap et al. (2017) menyatakan bahwa perlunya pendampingan pemasaran berbasis internet. Hal ini dapat dilakukan dengan memberikan wawasan tentang cara memaksimalkan teknologi yang ada untuk memasarkan produk mereka. Kristanto et al. (2018) mereka memberikan solusi layanan dengan mesin cetak hot press, bantuan pemasaran, pelatihan manajemen produksi, dan pemasaran untuk mengembangkan media pangsa pasar yang lebih luas. Sedangkan Octavia et al. (2016) (2016) memotivasi mitra untuk menggalakkan produk lokal menjadi produk unggulan. Tujuan dilakukannya adalah untuk menghadapi era Masyarakat Ekonomi ASEAN (MEA) tahun 2015. Selanjutnya Hadiyati et al. (2018) menyatakan bahwa adanya peningkatan kemampuan dalam tata kelola pemasaran produk dan pemasaran berbasis mobile marketing. Dari hasil berbagai pengabdian di atas, dapat diamati kinerja pengelola UKM menunjukkan peningkatan yang signifikan setelah proses pendampingan.

UKM Bank Sampah Mandiri adalah usaha jual beli sampah dari Dinas Kebersihan dan Pertamanan. Terkadang sampah didaur ulang dari kemasan Molto atau minyak kemasan dua kilogram. Hasil pendauran ulang adalah tas dan tisu yang akan dipasarkan melalui pameran terbuka. Awalnya, bisnis ini dibentuk dengan bantuan Nyat Khadir melalui Dinas Koperasi bersama ketua UKM yang bernama $\mathrm{Bu}$ Yarnis dengan alamat Batu Aji Permai Kavling Lama Blok E Nomor 1 RT 03 RW. 04 Kelurahan Sei Lekop Kecamatan Sagulung Batam. Jumlah tenaga kerja sebanyak 20 orang, yaitu 5 orang bagian membuat kue basah dan 5 orang lagi bagian catering lauk pauk, 6 orang bagian menjahit dari daur ulang sampah, 2 orang bagian pemasaran, dan 1 orang sisanya pada bagian keuangan. Pada musim Seleksi Tilawatil Qur'an (STQ), hasil pemasaran kue basah dan aneka tas banyak laku terjual dengan pesanan 20-50 bungkus.

\footnotetext{
${ }^{1}$ Program Studi Sistem Informasi, Fakultas Teknik dan Komputer, Universitas Putera Batam ${ }^{2}$ Program Studi Akuntansi, Fakultas IImu Sosial dan Humaniora, Universitas Putera Batam
}

\section{Korespondensi:}

Dian Efriyenti, Program Studi Sistem Informasi, Fakultas Teknik dan Komputer, Universitas Putera Batam

Email: dian.efriyenti@puterabatam.ac.id 
Dari pengamatan lapangan dan wawancara, UKM Bank Sampah Mandiri mengalami masalah pada pemasaran produksi dan pengelolaan keuangan. Secara umum, anggota UKM memiliki keterbatasan dalam menguasai teknologi informasi. Pemasaran hanya dilakukan kepada anggota keluarga UKM dan pameran oleh Dinas Koperasi. Padahal, penguasaan teknologi pada masa sekarang semakin mendesak. Contohnya persaingan di pasar lokal, regional, dan global, di mana setiap pelaku bisnis harus mulai memberikan informasi dengan cepat dan akurat kepada kliennya. Kurangnya tingkat pengetahuan anggota dalam memahami sistem informasi untuk memasuki persaingan pasar dunia dapat berdampak pada keberhasilan UKM itu sendiri.

Strategi pemasaran online dapat membantu bisnis beroperasi selama 24 jam dan mengakses dunia tanpa batas waktu. Jika mereka tidak mengikuti perkembangan teknologi, maka dapat tertinggal jauh dan kalah dalam persaingan. $e-$ commerce merupakan salah satu cara yang dapat dilakukan oleh pelaku usaha Kecil dan Menengah (UKM) untuk memasarkan produknya. Pemasaran berbasis e-commerce dapat menjual berbagai produk secara elektronik dari UKM kepada konsumen.

Masalah lain yang berkaitan dengan catatan keuangan harian adalah kelemahan sumber daya manusia dalam mencatat keuangan bisnis. Laporan keuangan belum mencakup standar akuntansi keuangan entitas tanpa akuntabilitas publik. Seringkali UKM menganggap akuntansi adalah hal yang merepotkan. Padahal, manfaat dari pembukuan dan pemasaran online adalah memfasilitasi operasi bisnis sebagai dasar analisis perkembangannya. Ini membuat UKM lebih meyakinkan jika ingin membangun kolaborasi dan kemitraan atau membuktikan kredibilitas untuk melakukan kredit. Salah satu cara untuk mengatasinya adalah dengan melakukan pembinaan penyusunan laporan keuangan dan pemberdayaan pemasaran berbasis e-commerce pada UKM Bank Sampah Mandiri Kota Batam.

\section{Metode}

Kegiatan pengabdiaan masyarakat akan dilaksanakan selama 3 Bulan, yaitu dari bulan Mei hingga Juli 2019. Bentuk kegiatan yang pertama yakni kunjungan untuk memberikan latihan pembinaan yang diberikan sebanyak 2 kali. Kunjungan dilaksanakan pada Senin dan Kamis pukul 13.0015.30 WIB yang bertempat di Batu Aji Permai Kavling Lama Blok E No 1 RT 03 RW. 04 Kelurahan Sei Lekop Kecamatan Sagulung Batam. Narasumber dari dari kegiatan ini adalah 2 orang dosen dan satu mahasiswa.

Pertemuan ke satu dilaksanakan pada minggu ke tiga bulan mei 2019. Dilaksanakan sosialisasi tentang gambaran umum dan peran penting akuntansi UKM. Disertai Penjelasan siklus akuntansi dari jurnal umum, buku besar, neraca saldo, sampai dengan laporan keuangan. Berikutnya pertemuan ke dua pada minggu ke tiga bulan Juni 2019. Diadakan penjelasan materi pemasaran berbasis e-commerce dengan memasarkan produk berbasis web bagi para pelaku dan pembinaan UKM untuk mempunyai surat elektronik (e-mail) sebagai sarana komunikasi data dengan konsumen.

Selain materi pemasaran e-commerce, dilakukan pula penjelasan mengenai panduan akuntansi berdasarkan situasi kehidupan nyata. Pemahaman akuntansi diharapkan dapat membantu UKM mengelola sumber dana mereka dan menggunakannya dengan efektif. Harapannya, UKM dapat mengembangkan dan perekonomian Indonesia, memahami komunikasi pemasaran email, dan menggunakan pemasaran produk berbasis web.

Kegiatan ini terlaksana dengan beberapa metode pelaksanaan. Metode pertama yaitu wawancara dan pelatihan. Disana ditemukan permasalahan yaitu minimnya pengetahuan tentang pembukuan keuangan sesuai standar entitas tanpa akuntabilitas publik. Sebagai solusi, diberikan pelatihan dalam menyusun laporan keuangan secara tahunan ataupun bulanan. Pula diadakan pelatihan dan diskusi mengenai pengelolaan e-commerce melalui email/ online dan manajemen pemasaran online. Mengingat bahwa masih minimnya pengetahuan dalam mengadopsi perkembangan teknologi baru berbasis e-commerce.

Peserta diberikan seperangkat alat tulis untuk memaksimalkan pelatihan. Selain itu, UKM akan menerima modul yang berisi materi tentang konsep dan teknik dasar untuk menyiapkan laporan keuangan dan pemasaran online. Kegiatan ini dibagi menjadi beberapa fase. Fase pertama adalah penyediaan bahan tentang konsep dasar kesetaraan dasar akuntansi UKM, survei praktis, dan teknik akuntansi untuk UKM. Materi mencakup penyelesaian kasus transaksi penjualan UKM dan biaya yang terdiri dari jurnal, neraca, hingga laporan keuangan. Kemudian fase kedua adalah aktivitas diskusi dan tanya jawab. Selanjutnya adalah latihan dan bimbingan tentang pemasaran berbasis web, mengingat pentingnya penggunaan teknologi informasi melalui e-commerce agar tidak tertinggal jauh dalam persaingan tingkat global.

Pengabdian ini dilakukan dengan metode ceramah, tutorial, diskusi, serta latihan. Adapun sistematika pelaksanaannya adalah sebagai berikut: a. Langkah 1 (Metode Ceramah): Peserta termotivasi untuk menerapkan akuntansi dalam operasi bisnis mereka. Selain itu, peserta diberi materi tinjauan umum dan peran penting akuntansi UKM. Langkah pertama diadakan selama 1 jam dengan media e-mail, Skype, dan pembuatan situs web online.

b. Langkah 2 (Metode Tutorial): Peserta mendapatkan materi akuntansi, mulai dari bukti-bukti fisik yang diinput ke dalam jurnal hingga pelaporan keuangan, disertai dengan pelatihan untuk membuat web pemasaran produk digital. Langkah kedua berdurasi selama 2 jam.

c. Langkah 3 (Metode Diskusi): Peserta dapat membahas isu-isu terkait keuangan UKM dan teknologi informasi yang dihadapi sejauh ini. Langkah ketiga berdurasi selama 1 jam.

d. Langkah 4 (Metode Latihan) Tujuan dilakukannya latihan adalah melatih UKM untuk menganalisis transaksi pada sebuah laporan keuangan dan cara memasarkan barang secara online melalui e-commerce. Manfaat dari laporan keuangan ini tidak hanya untuk pihak internal, tetapi juga pihak eksternal. Laporan keuangan berguna jika UKM ingin memperluas bisnis mereka atau menambah modal dengan mengajukan pinjaman kepada debitur.

Evaluasi kegiatan ini dilakukan rutin bersama tim pengabdian agar diketahui seberapa jauh tingkat keberhasilannya. Evaluasi pengabdian tertera pada tabel di bawah.

Pada tahap ini, kegiatan observasi dan evaluasi dilakukan. Observasi yang dilakukan adalah membedah laporan keuangan dan pemasaran online atau e-commerce yang disiapkan oleh UKM. Instrumen yang digunakan yaitu 
Tabel 1. Evaluasi Dalam Pembinaan

\begin{tabular}{|c|c|c|}
\hline Tujuan & Indikator Ketercapaian & Tolok Ukur \\
\hline $\begin{array}{l}\text { Memberikan pembinaan akuntansi } \\
\text { bagi UKM Bank Sampah Mandiri }\end{array}$ & $\begin{array}{l}\text { Penguasaan akuntansi yang sesuai } \\
\text { SAK-ETAP dengan mudah dan cepat } \\
\text { akan memberikan manfaat dalam hal } \\
\text { pengelolaan keuangan. }\end{array}$ & $\begin{array}{l}\text { UKM mampu menyusun laporan } \\
\text { keuangan secara bulanan dan } \\
\text { tahunan. }\end{array}$ \\
\hline $\begin{array}{l}\text { Memberikan pelatihan melalui media } \\
\text { komunikasi dengan konsumen } \\
\text { melalui email, Skype, dan pemasaran } \\
\text { produk berbasis web. }\end{array}$ & $\begin{array}{l}\text { UKM tahu pentingnya pemasaran } \\
\text { berbasis e-commerce sehingga pro- } \\
\text { duk yang diproduksi lebih mudah } \\
\text { diketahui publik dan meningkatkan } \\
\text { persaingan dalam globalisasi infor- } \\
\text { masi. }\end{array}$ & $\begin{array}{l}\text { UKM dapat menjadikan email atau } \\
\text { skype sebagai sarana berkomunikasi } \\
\text { dengan pelanggan. Selain itu dapat } \\
\text { mengoperasikan media pemasaran } \\
\text { melalui blog dan web agar produk } \\
\text { lebih dikenal masyarakat. }\end{array}$ \\
\hline
\end{tabular}

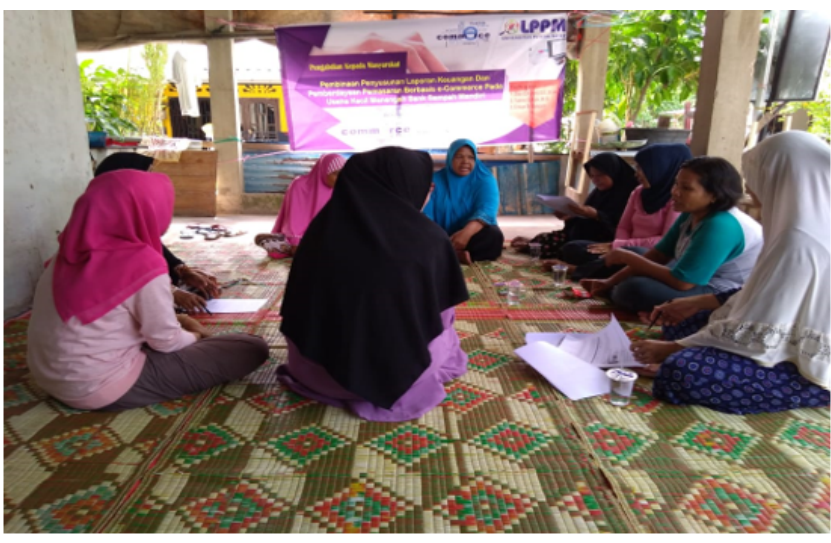

Gambar 1. Penyampaian materi pengabdian

catatan lapangan. Beberapa hal yang diamati yakni keterbatasan, kekurangan, dan kelemahan yang muncul dalam penyusunan laporan keuangan.

Keberlanjutan dari hasil kegiatan hendaknya memiliki nilai positif di berbagai pihak, terutama pelaku UKM dalam pencatatan keuangan dan pemasaran. Penguasaan akuntansi dan teknologi informasi dengan mudah dan cepat akan memberikan manfaat dalam hal pengelolaan keuangan dan pemasaran berbasis web. Pelatihan akuntansi dengan pendekatan yang tepat akan menjadikan pelaku UKM memahami materi dengan mudah dan cepat. Diharapkan pelatihan ini dapat membantu pelaku UKM untuk mengelola sumber dana dan penggunaan serta memudahkan akses pasar di era global sehingga UKM dapat berkembang lebih baik. Adapun keberlanjutan kegiatan ini adalah sebagai berikut: 1) Mampu memahami pencatatan keuangan dan tujuannya. 2) Mampu menganalisis dan membuat laporan keuangan secara mandiri sesuai dengan siklus akuntansi setiap periodenya. 3) Mampu mengelola pemasaran aplikasi web pemasaran berbasis e-commerce. 4) Mampu menggunakan email atau Skype sebagai sarana komunikasi data lainnya.

\section{Hasil}

Pembinaan ini telah direalisasikan sebanyak 2 kali pertemuan yang dilaksanakan setiap pukul 14.00 - 17.00 WIB. Pembinaan dilakukan kepada 8 orang dari Ibu kelompok UKM Bank Sampah Mandiri. Teknis pelaksanaan pembinaan dilakukan dengan metode ceramah, diskusi, dan latihan Berdasarkan metode tersebut, maka tim pengabdi secara langsung memandu dan membina UKM dalam penyusunan laporan keuangan sesuai dengan SAK-ETAP dan pemasaran berbasis online atau e-commerce. Adapun penjelasan pada setiap pertemuan sebagai berikut:

1. Pertemuan Pertama Dilaksanakan pada Kamis, 11 Juli 2019, di mana kegiatan pertemuan saat itu diawali dengan pembukaan oleh ketua, penyampaian materi "Pengantar Akuntansi UKM dan Penyusunan Laporan Keuangan”. Materi ini membahas pentingnya akuntansi UKM dan membahas soal tentang laporan keuangan sehari-hari. Materi disampaikan oleh ketua.

Materi kedua disampaikan oleh anggota 2 dengan topik siklus akuntansi, yang dimulai dari transaksi pada jurnal umum, buku besar, dan neraca saldo. Sedangkan materi ketiga disampaikan oleh anggota 1 terkait transaksi-transaksi keuangan, yang berupa laporan laba rugi, laporan perubahan ekuitas, dan laporan posisi keuangan.

2. Pertemuan Kedua Dilaksanakan pada Senin, 15 Juli 2019, kegiatan ini berfokus untuk membina para pelaku UKM supaya dapat mengimplementasikan e-commerce. Materi disampaikan oleh ketua pada pukul 14.00 dan dilanjutkan oleh anggota 1 terkait penjelasan materi pada marketplace. Materi ini menekankan interaksi antara penjual dan pembeli melalui transaksi elektronik. Dalam tradisional marketplace, lalu lintas informasi, produk atau jasa, dan pembayaran masih bersifat fisik. Sebaliknya, dalam dunia virtual marketplace, aliran informasi produk, proses komunikasi antara produsen dan konsumen, distribusi barang atau jasa, dan transaksi berlangsung dalam dunia maya.

Materi selesai pada pukul 15.00-16.00 WIB dan dilanjutkan bentuk media e-commerce untuk pemberdayaan pemasaran online, yang dipaparkan oleh anggota 1. Materi ini mengupas cara melakukan pemasaran di website UKM, pemasaran produk di Facebook dan Instagram, dan bentuk pemasaran tradisional yang masih terjadi yaitu penjualan catering berdasarkan pesanan keluarga, tetangga, atau kerabat. Pada jam 16.00, tim pengabdi memberikan sesi latihan yang didampingi oleh dua anggota untuk mendapat feedback. Peserta diberikan kesempatan untuk mendiskusikan permasalahan yang berkaitan dengan usaha yang sudah mereka jalani dengan pendampingan anggota kelompok.

Kegiatan berjalan sesuai rencana. Pada materi pertama, sebagian besar audiens belum mengerti fungsi akuntansi, bahkan ada yang menganggap bahwa akuntansi amat rumit, merepotkan, dan menghabiskan waktu.

Materi pertama berisi tentang pentingnya akuntansi bagi usaha kecil (UKM) dan data-data transaksi yang harus dimasukan didalam jurnal umum. Pada sesi ini, terjadi diskusi 
yang menarik antara audience dengan pemateri mengenai konsep dasar terkait usaha yang UKM tekuni. Dilanjutkan materi kedua mengenai transaksi-transaksi akuntansi UKM, yaitu transaksi pembelian dan transaksi penjualan. Selanjutnya diidentifikasi aktivitas-aktivitas ekonomi terkait pencatatan akuntansi. Aktivitas yang diidentifikasi tersebut diawali dari memulai usaha (investasi awal), transaksi pembelian bahan baku, pembelanjaan atau pengeluaran, dan pemasukan atau penerimaan. Setelah mencatat transaksi akuntansi, materi berikutnya adalah menyusun laporan keuangan. Sebagai latihan, peserta pembinaan diminta untuk menjawab soal latihan yang telah disediakan menggunakan bantuan formulir jurnal umum, posting buku besar, dan formulir laporan keuangan. Pada sesi terakhir, peserta melakukan diskusi terkait pencatatan keuangan di usaha UKM.

Pembinaan hari kedua dilaksanakan hari Senin, 15 Juli 2019. Peserta diberikan gambaran tentang materi dan praktik laporan keuangan, yang terdiri dari laporan laba rugi, laporan perubahan ekuitas, transaksi pembelian, dan transaksi penjualan. Pada sesi awal, peserta berdiskusi tentang transaksi dan pencatatan yang telah mereka buat. Beberapa peserta masih kebingungan mencatat transaksi akuntansi. Diskusi dilanjutkan dengan santai sembari membahas praktik penyusunan laporan keuangan. Selanjutnya adalah latihan pembukuan pemasaran secara online. Sebelumnya, tim mengevaluasi tugas peserta. Tim memulai materi keutamaan pemasaran secara online yang disampaikan oleh anggota 1. Kemudian dilakukan didampingi untuk membuat laman sosial media dan merumuskan langkahlangkah strategis untuk memaksimalkan penjualan produk. Pembinaan tersebut dilakukan oleh anggota 2. Media dalam pelatihan ini adalah Facebook, Instagram dan laman website sebagai sarana melakukan proses promosi.

Indikator tercapainya tujuan pengabdian ini adalah pembuatan catatan transaksi usaha yang dicatat secara tepat pada buku besar kas masuk dan keluar, buku pembelian dan penjualan, serta laporan keuangan. Sementara itu, indikator tercapainya pembinaan pemasaran online adalah tersedianya laman media sosial UKM dan peserta paham tentang apa yang harus dilakukan pada laman tersebut. Hasil pelaksanaan kegiatan ini akan menjadi masukan untuk keberlanjutan pengabdian di tahun yang akan datang. Pada kegiatan pengabdian ini tentu ada kendala meskipun tidak signifikan. Adapun kendala-kendala tersebut adalah:

1. Sebagian besar peserta yang menyusun laporan keuangan belum sesuai standar akuntansi keuangan entitas tanpa akuntabilitas publik. 2. Belum ada pemisahan laporan keuangan yang telah biasa disusun oleh UKM melalui keuntungan usaha dan kas pribadi. 3. Media promosi penjualan masih bersifat fisik.

Permasalahan yang dihadapi dapat dievaluasi dengan cara sebagai berikut: 1 . Pengabdian ini dapat dilaksanakan secara berkelanjutan hingga peserta mengerti dan secara mandiri mampu menyusun laporan keuangan mereka sesuai standar. 2. Perbedaan antara keuntungan usaha dan kas pribadi dapat dipraktikan di transaksi yang terjadi seharihari, sehingga terlihat perbedaan catatan keuangan usaha dengan catatan keuangan pribadi. 3. Media promosi penjualan masih bersifat tradisional, sehingga dengan adanya pemberdayaan pemasaran e-commerce diharapkan dapat memperluas pasar hingga taraf global, memgurangi biaya pembuatan dan pendistribusian, meningkatkan brand usaha, dan mempercepat proses bisnis. Pelayanan dapat berlangsung tanpa ada batasan waktu 1x24 jam, efektivitas dalam pengiriman, dapat melakukan review terkait produk dan dapat memberikan informasi lebih cepat. 4. Tim pengabdi selalu melakukan follow up selesai kegiatan. Lewat evaluasi, dapat ditemukan kendala yang dihadapi saat pengabdian dilaksanakan. Hasil evaluasi akan ditindaklanjuti sesuai dengan kendala yang dihadapi.

\section{Kesimpulan}

Berdasarkan hasil dan pembahasan, maka didapatkan simpulan sebagai berikut: 1 . UKM yang sudah dibina dapat melakukan penyusunan laporan keuangan secara mandiri berstandar SAK-ETAP. 2. Perlu adanya latihan keberlanjutan tentang keuangan usaha dan kas pribadi sehari-hari dalam usaha kegiatan pelaku UKM. 3. Perlu adanya latihan dan praktik mandiri sehari-hari sehingga dapat membiasakan dalam kebutuhan usahanya.

\section{Referensi}

Afrida, A., Harizon, H., Bakar, A., \& Sanova, A. (2018). Pelatihan Pengembangan Media Pembelajaran Interaktif Berbasis Multimedia Sebagai Upaya Meningkatkan Kompetensi Profesionalisme dan Kreativitas Guru-Guru SMA Muaro Jambi. Jurnal Karya Abdi Masyarakat, 2(1), 15-22. DOI: https://doi.org/10.22437/jkam.v2i1.5426

Dinas Kependudukan dan Catatan Sipil Kota Batam (2015). Data Penduduk Kota Batam tahun 2015. Batam.

Hadiyati, E., Gunadi, \& Arwani, I. (2018). Pelatihan Tata Kelola Pemasaran Produk Berbasis Mobile Marketing UKM Industri Perak. Jurnal ABDIMAS Unmer Malang, 3(2), 33-43. https://doi.org/10.26905/abdimas.v3i2.2590

Harahap, K., Lubis, I., \& Effiyanti, T. (2017). Inisiasi Pemasaran Daring Di Kelompok Usaha Melur Di Desa Sambirejo, Kecamatan Precut Sei Tuan. Jurnal Pengabdian Kepada Masyarakat, 23(1), 1-12. https://doi.org/10.24114/jpkm.v23i1.6640

Kementrian Keuangan (2016). UMKM Berpotensi Tingkatkan Pertumbuhan Ekonomi Indonesia. diunduh dari https://www.kemenkeu.go.id/publikasi/berita/umkmberpotensi-tingkatkan-pertumbuhan-ekonomi-indonesia/

Kristanto, T., Muliawati, E. C., Arief, R., \& Hidayat, S. (2018). Peningkatan kualitas produksi UKM percetakan di Karangpilang Surabaya dan Krian Sidoarjo. Aksiologiya: Jurnal Pengabdian Kepada Masyarakat, 2(1), 33-38. http://dx.doi.org/10.30651/aks.v2i1.1200

Octavia, A., Erida, S., \& Iskandar, S. (2016). Pelatihan Kewirausahaan dan Manajemen Bagi Ibu Rumah Tangga, Remaja Putri dan Kelompok Usaha Bersama Mutiara Kota Jambi. Jurnal Pengabdian Pada Masyarakat, 31(3), 36-41. https://doi.org/ISSN: 2548-7159 